\title{
Inhibition of Complement as a Therapeutic Approach in Inflammatory Central Nervous System (CNS) Disease
}

\author{
Scott R. Barnum, Ph.D. \\ Department of Microbiology, The University of Alabama at \\ Birmingham, Birmingham, Alabama, U.S.A.
}

\section{Introduction}

In recent years it has become clear that inflammation and tissue destruction in central nervous system (CNS) disease is due, at least in part, to the activation of complement. Although often implicated in contributing to the pathology of diseases such as multiple sclerosis (MS), Alzheimer's disease, and many others, how central the role of complement is to the pathology of these diseases remains controversial. Interestingly, studies in the last few years have demonstrated endogenous synthesis of complement system proteins by most CNS cell types (including complement anaphylatoxin receptors that mediate most of the inflammatory effects of the complement system) (1-4). This information, combined with a number of animal model studies in which inhibition of complement activation leads to a favorable disease outcome (both in and out of the CNS), now make it evident that the development of complement therapeutics for CNS disease merits more attention than received in recent years.

As will be discussed below, the difficulty of targeting the complement system for therapeutic intervention lies with the large number of proteins, several pathways, and numerous receptors that mediate complement host defense functions (see Fig. 1). Targeting the appropriate complement protein or proteins is further complicated by the fact that the details of the roles each activation peptide and receptor plays in CNS disease are largely unknown. However, insight

Address correspondence and reprint requests to: Dr. Scott R. Barnum, Department of Microbiology, The University of Alabama at Birmingham, 701 19th St. S., LHR/141, Birmingham, AL 35294, U.S.A. Phone: 205-934-4972; Fax: 205-934-4985; E-mail: sbarnum@uab.edu from the success of complement inhibition studies outside the CNS, as well as a few studies in CNS disease models, will prove useful as rational starting points in designing new therapeutic agents and applying those therapeutics currently in use $(5,6)$. This review will focus on how complement contributes to inflammation in the brain, where intervention in the complement system may prove useful, and the currently available repertoire of inhibitors that hold therapeutic potential. The reader is also referred to several excellent recent reviews on therapeutic inhibition of complement outside the CNS (510).

\section{Potential}

Although still largely untested, complement therapeutics in CNS disease could have a major impact on the health and quality of life for individuals with a number of different diseases. For example, complement activation has been strongly implicated in the inflammation associated with Alzheimer's disease (reviewed in refs. $1,11)$. It is estimated that over 4 million persons in North America alone are affected by Alzheimer's disease (Table 1) (12). Worldwide this number may be as large as 20 million and, with the increased life span enjoyed by postindustrial societies, these numbers will increase in the coming decades. Complement therapeutics that alter the course of Alzheimer's disease would then affect a large segment of the population and could significantly reduce the costs associated with the health and daily care of these individuals (estimated at as much as $\$ 100$ billion per year) (13). The ability of a complement therapeutic to produce a clinical outcome of even a 


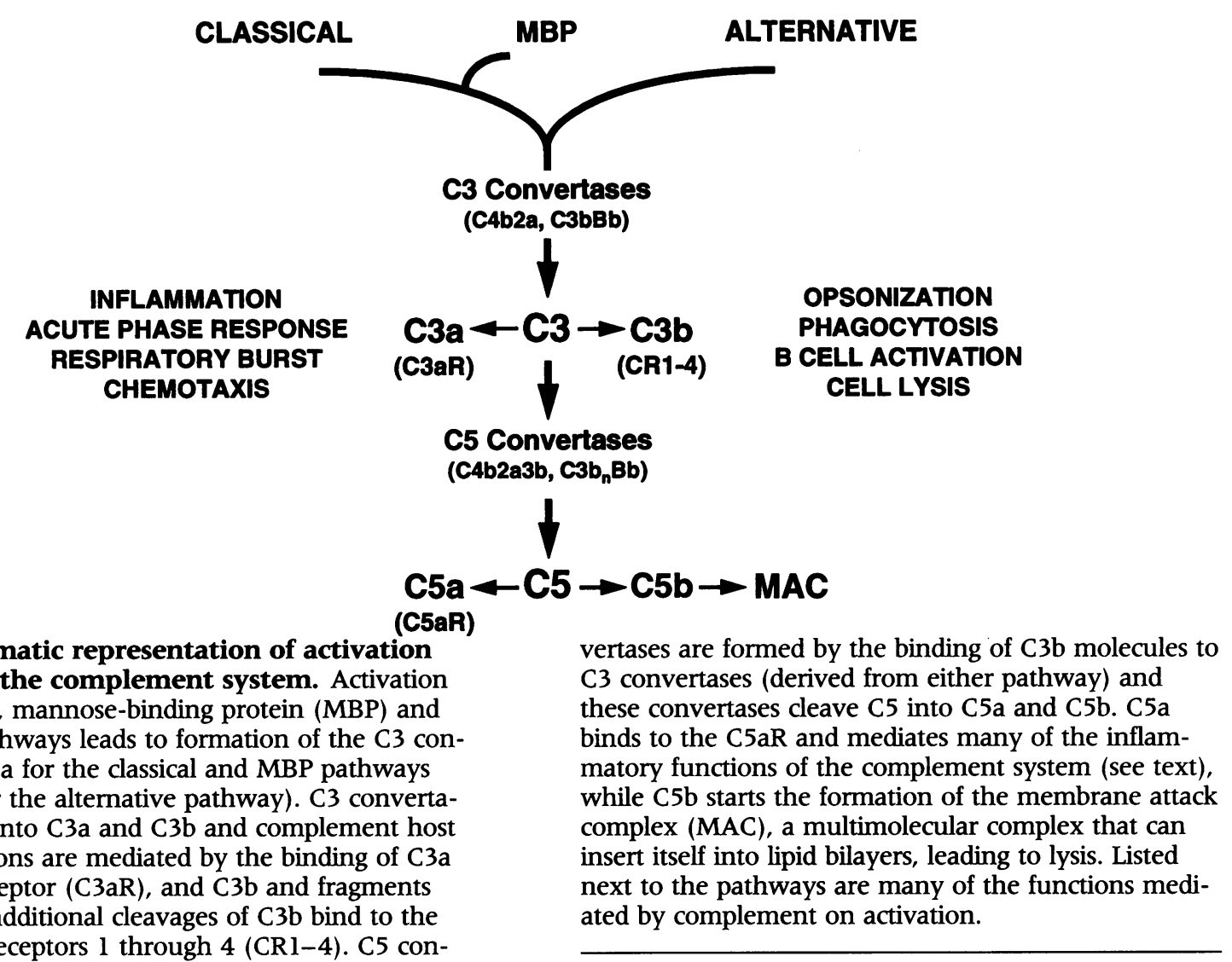

Fig. 1. Schematic representation of activation pathways of the complement system. Activation of the classical, mannose-binding protein (MBP) and alternative pathways leads to formation of the $\mathrm{C} 3$ convertases (C4b2a for the classical and MBP pathways and $\mathrm{C} 3 \mathrm{bBb}$ for the alternative pathway). $\mathrm{C} 3$ convertases cleave $\mathrm{C} 3$ into $\mathrm{C} 3 \mathrm{a}$ and $\mathrm{C} 3 \mathrm{~b}$ and complement host defense functions are mediated by the binding of $\mathrm{C} 3 \mathrm{a}$ to the $\mathrm{C} 3 \mathrm{a}$ receptor $(\mathrm{C} 3 \mathrm{aR})$, and $\mathrm{C} 3 \mathrm{~b}$ and fragments derived from additional cleavages of $\mathrm{C} 3 \mathrm{~b}$ bind to the complement receptors 1 through $4(\mathrm{CRl}-4)$. C5 con-

modest delay in onset or progression of Alzheimer's disease would also lead to a greater quality of life than that resulting from any currently available treatment. Similar arguments can be made for a number of additional inflammatory CNS conditions in which complement has been implicated. These conditions, along with the estimated numbers of affected individuals in the U.S. alone, are listed in Table 1. It is clear from Table 1 that millions of individuals could benefit

Table 1. Central nervous system diseases or conditions associated with complement activation

\begin{tabular}{lc}
\hline Disease/condition & $\begin{array}{c}\text { Number of affected } \\
\text { individuals } \\
\text { (approximate) }\end{array}$ \\
\hline Alzheimer's disease & $4,000,000$ \\
Meningitis & $25,000-50,000$ \\
Multiple sclerosis & 300,000 \\
Stroke & 500,000 \\
Traumatic brain injury & 500,000 \\
\hline
\end{tabular}

annually from effective complement therapeutics for CNS disease.

\section{Sources of Complement in the CNS}

Perhaps the most surprising fact for clinicians and many individuals in the fields of immunology and neuroimmunology is that the brain is a rich source of complement components. As shown in Table 2, studies in the last decade have demonstrated that essentially all of the activation components, regulatory molecules, and receptors of the complement system are produced by astrocytes, microglia, and neurons $(1,2,4,11,14,15)$. Although most of the data in these studies are from in vitro work, there is increasing evidence from rodent model systems and human brain tissue that complement synthesis occurs in vivo in acute and chronic inflammatory settings. Under normal conditions, complement proteins can be found at low levels in cerebrospinal fluid (CSF) (reviewed in refs. 1,16). These proteins are likely derived from low levels of in situ production and from leakage around the circumventricu- 
Table 2. Central nervous system production of complement proteins and receptors

\begin{tabular}{ll}
\hline Cell type & \multicolumn{1}{c}{ Complement component } \\
\hline Astrocyte & $\mathrm{C} 1-\mathrm{C} 9$, factors B, D, H, I, C1-INH, C4BP, DAF, MCP, CD59, clusterin, C3aR, C5aR, CR2 \\
Microglia & $\mathrm{C} 1, \mathrm{C} 3, \mathrm{C} 4$, clusterin, C1-INH, CD59, CR1, CR3, CR4, ClqR, C3aR, C5aR \\
Neuron & $\mathrm{C} 1-\mathrm{C} 9$, factor B, CD59, DAF, C1-INH, clusterin, CR1, C3aR, C5aR \\
Oligodendrocyte & $\mathrm{CD} 59, \mathrm{DAF}, \mathrm{C3aR}, \mathrm{C} 5 \mathrm{aR}$ \\
Ependymal & $\mathrm{C} 3, \mathrm{C} 5 \mathrm{aR}$
\end{tabular}

Data derived from references $(1,2,4,11,14,15)$.

lar organs (17). Under inflammatory conditions, such as in bacterial meningitis or traumatic brain injury, CSF levels of at least some complement components may increase significantly $(18,19)$. In addition to being produced in the CNS, complement is readily activated by CNS-specific proteins and peptides including myelin, myelin basic protein and other myelinderived proteins, and amyloid peptides such as A $\beta$ 1-42 (reviewed in ref. 1).

In acute or chronic inflammatory disease settings in the CNS, endogenous complement production may increase dramatically, as has been reported in Alzheimer's disease $(3,11)$, bacterial meningitis (20-22), MS and the animal model for MS, experimental allergic encephalomyelitis (EAE) (23-27), stroke (S. R. Barnum et al., unpublished findings), and traumatic brain injury (28) or lesioning model systems (29). In addition, transgenic model systems in which acutephase response cytokines are overexpressed in the CNS (reviewed in ref. 30) have provided evidence for increased expression of some complement components by glial cells and neurons $(31,32)$. Although much remains to be done in these model systems, there is little doubt that complement production is an integral part of the inflammatory response in the CNS.

\section{How Complement Contributes to Inflammation}

The complement system is well known for its role in inflammation and perhaps best known for its ability to lyse invading pathogens and eucaryotic cells. An understanding of the molecular basis of how complement activation contributes to inflammation has increased greatly in the last decade. For a more in-depth treatment of this subject, the reader is referred to an excellent text edited by Volanakis and Frank, that covers the biochemistry and biology of complement (33), and that edited by Morgan and Harris which covers the regulation of complement (8).

Aside from causing degranulation of mast cells and basophils, leading to increased vascular permeability and edema, the anaphylatoxins $\mathrm{C} 3 \mathrm{a}$ and $\mathrm{C} 5 \mathrm{a}$ are pivotal to complement-mediated inflammatory events. These include activation of macrophages and neutrophils, the respiratory burst, and enhancement of the acute-phase response (reviewed in refs. 34,35). More specifically, C5a can induce the expression of a number of proinflammatory cytokines and CXC and CC chemokines from macrophages $(35,36)$. Most if not all of these cytokines have been implicated in contributing to the pathogenesis of the CNS diseases listed in Table $1(30,37-39)$. Furthermore, $\mathrm{C} 5 \mathrm{a}$ has been shown to act as an acute-phase "cytokine" on the basis of its ability to modulate the expression of acute-phase proteins (including increased expression of some complement proteins) by hepatocytes (40). Recent studies have demonstrated that, in vitro, astrocytes produce interleukin-6 (IL-6) in response to exposure to $\mathrm{C} 3 \mathrm{a}$ and $\mathrm{C} 5 \mathrm{a}(41)$, potentially providing the CNS with a similar mechanism for inducing cytokine production. Additional studies have indicated that chemokine production may be synergistically enhanced in the presence of the membrane attack complex (MAC) and a costimulus such as immune complexes (42). It remains to be demonstrated whether similar mechanisms are at work in the CNS; however, there is clear evidence for the presence of the MAC in Alzheimer's disease and MS brain $(43,44)$, leaving open the possibility that multi- 
ple activated complement peptides (C5a) or complexes (the MAC) may aid in chemokine production.

The C3a and C5a anaphylatoxins are also potent chemoattractants capable of attracting mast cells, basophils, eosinophils, macrophages, and neutrophils (reviewed in ref. 35). Recent studies have shown that $\mathrm{T}$ and $\mathrm{B}$ cells express the $\mathrm{C} 5 \mathrm{a}$ receptor $(\mathrm{C} 5 \mathrm{aR})$ and that both cell types are chemoattracted to $\mathrm{C} 5 \mathrm{a}$ at nanomolar concentrations $(26,45)$. Astrocytes and microglia are also chemotactic for C5a $(46,47)$. This finding, combined with the fact that $\mathrm{C} 5 \mathrm{a}$ is capable of inducing increased expression of adhesion molecules $(48-50)$, indicates that C5a may not only recruit infiltrating macrophages and lymphocytes to sites of inflammation in the CNS but also aid in their adhesion molecule-dependent trafficking across the blood-brain barrier. The high expression of the C5aR on endothelial vessels in the lumbar spinal cord in EAE provides further support for this concept (25). The MAC may also contribute to trafficking, according to recent data from Kilgore et al. (51), in which neutrophil adhesion to endothelial cells was induced by MAC and platelet-activating factor-dependent up-regulation of P-selectin. Thus local production and activation of complement in response to trauma, infection, or autoimmune responses may contribute to induction of inflammation at the earliest stages of an immune response. Since complement gene expression by glial cells and neurons is readily up-regulated by cytokines (reviewed in refs. $1,2,4)$, a vicious circle of increasing inflammation may ensue until anti-inflammatory mechanisms intervene.

\section{What to Target in the Complement System}

The complement system presents a unique challenge in terms of targeted inhibition of its multiple host defense functions. To date there are no small molecule inhibitors in use in humans that can safely block complement activation, either systemically or in the CNS compartment, without inhibiting a myriad of other essential serine proteases. Furthermore, although some proteinbinding sites of the components that comprise the $\mathrm{C} 3$ and $\mathrm{C} 5$ convertases (see Fig. 1) and the MAC have been identified by mutagenesis, structure determination, or INDEL mapping analysis (52), there is still much we do not know about the interaction and structural and functional fea- tures of many of the proteins in this system. For more detailed information on protein-protein interactions and protein-binding sites in the complement system, the reader is referred to Volanakis and Frank (33).

There are several approaches available for targeting the complement system for pharmacological inhibition. Often the classical pathway is chosen over the alternative (or vice versa) because of the belief that activation of one pathway is mutually exclusive of the other, particularly if a pathwayspecific activator appears to be the primary activator in a given disease. This was initially the case in Alzheimer's disease, for example, as a number of well-performed studies demonstrated activation of the classical pathway through interaction of $\mathrm{Clq}$ with the amyloid peptide $A \beta$ 1-42 (53-55). However, it has subsequently been shown that $A \beta$ 1-42 peptides can activate the alternative pathway as well, which suggests that targeting one pathway could fail to provide adequate protection against complement-mediated inflammation and damage $(56,57)$. In addition, there is substantial evidence of cross-pathway activation in the complement system, making targeted inhibition of a single pathway less therapeutically desirable $(58-60)$.

As the activation pathways of complement converge to generate $\mathrm{C} 3$ and $\mathrm{C5}$ convertases, which cleave $\mathrm{C} 3$ and $\mathrm{C} 5$, respectively, into their biologically active fragments (see Fig. 1), it seems reasonable that targeting the functional activity of the convertases would be preferable to pathway-specific proteins such as $\mathrm{Cl}$ or factor $\mathrm{D}$. This is because inhibiting complement activation at the level of the convertases, particularly the $\mathrm{C} 3$ convertase, will block the great majority of inflammatory and lytic host defense functions of complement and only one inhibitor would be required to block complement activation. The regulatory biology of the complement system supports this concept, as most of the serumsoluble and membrane-bound complement regulatory proteins function to inhibit the formation or stability of the C3 convertases of both pathways. These proteins include decay-accelerating factor (DAF), membrane cofactor protein (MCP), complement receptor type 1 (CR1), C4b binding protein (C4BP), and factors $\mathrm{H}$ and $\mathrm{I}$. There is also evidence from a number of in vivo model studies that demonstrates that inhibition at the level of the $\mathrm{C} 5$ convertase, by preventing the cleavage of $\mathrm{C} 5$ through the use of an anti-C5 antibody, provides substantial protection against complementmediated inflammation and damage (61). Thus inhibiting complement at the level of the $\mathrm{C} 3$ and 
C5 convertases appears to provide a highly promising set of targets for continued therapeutic development.

The MAC is a further therapeutic target and its destructive function has lead to a significant effort to find ways to block the formation of the MAC on tissues. Many of these studies involve the generation of transgenic animals expressing CD59, a GPI-anchored protein that inhibits the binding of $\mathrm{C} 9$ to $\mathrm{C} 8$ and the binding of additional C9 molecules into the developing MAC pore $(8,62)$. These animals are primarily used for developing ways to overcome complement-mediated damage and destruction of transplanted tissue (reviewed in refs. 6,10). The obvious shortcoming of this approach is that inhibition of the MAC alone does not prevent the generation of the anaphylatoxins, whose effects are potentially life threatening. How important such transgenic tissues would be for CNS applications is unclear at this time and the continued development of new and more specific immunosuppresive reagents may overcome the need for complement transgenic tissues all together (63). The use of MAC inhibitors alone seems unlikely, but they may prove useful in combination with therapeutics that inhibit convertase activity. For example, the use of anti-C8 antibodies in combination with anti-C5 antibodies or a novel chimeric composed of CD59 and DAF have been shown to inhibit both convertase activity and MAC assembly $(64,65)$. Studies have suggested that CD59 in liposomes may prove to be a useful way to deliver this complement inhibitor in a soluble form (66). This might be of value in acute disease settings such as bacterial meningitis, where inhibiting complement activation and the subsequent release of bacterial cell wall fragments (due in part to MAC-induced cell lysis) may reduce the massive inflammatory response that contributes to CNS edema and neurological damage (reviewed in ref. 67).

Finally, targeting the anaphylatoxin receptors $\mathrm{C} 3 \mathrm{aR}$ and $\mathrm{C} 5 \mathrm{aR}$ is important, as these seven transmembrane-spanning, G protein-coupled receptors are central to the inflammatory events seen on complement activation. A significant amount of effort to determine the structural features and contact points of the ligand-binding sites has yielded models of receptor-ligand interaction and provided some insight for the development of receptor antagonist therapeutics. For the C5aR, a "two-point" binding model has been used, in which the amino terminus of the C5aR binds core residues of C5a while several residues found in the extracellular loops and transmembrane helices (Glu 199 and Arg 206, in particular) bind the carboxy-terminal region of $\mathrm{C} 5 \mathrm{a}$ (reviewed in refs. 34,35,68). For the C3aR, the amino-terminal portion of the receptor is not required for high-affinity binding and activation by $\mathrm{C} 3 \mathrm{a}$, and replacement of the $\mathrm{C} 3 \mathrm{aR}$ amino terminus with that of the C5aR leads to the formation of a hybrid receptor that binds and functionally responds to both C3a and C5a (69). Receptor agonists and antagonists will be described below.

\section{Currently Available Inhibitors and Their Application}

There are a number of complement-specific inhibitors in clinical trials or in various stages of development. These inhibitors target primarily the $\mathrm{C} 3$ and $\mathrm{C} 5$ convertases, although there has been a substantial effort to design inhibitors specific for early classical and alternative pathway activation proteins ( $\mathrm{Clr}, \mathrm{Cls}$, and factor $\mathrm{D})$. These inhibitors as well as more recently described molecules will be described below.

\section{Complement Receptor Type 1 and Derivatives}

$\mathrm{CR} 1$ is a membrane-bound complement regulatory protein composed almost exclusively of a short-repeat motif known as a short-consensus repeat (SCR) or a complement control protein module (CCP) (70) (see Fig. 2). The most common allotype (type A) has 30 SCRs, the first 28 of which are organized into long homologous repeat (LHR) units of 7 SCRs each. The first two SCRs of the first LHR (LHR-A) have binding specificity for C4b while the first two SCRs of the subsequent LHRs (LHRs B and C) have specificity for $\mathrm{C} 3 \mathrm{~b}$. Mutagenesis studies have identified residues important in C3 binding specificity for LHRs B and C (71). This information, combined with the recent crystallization and $\mathrm{X}$-ray diffraction analysis of the SCRs of DAF (72), may allow the identification of essential structural features of the C3b binding site of CRl. Such information may lead to the development of much smaller CR1 structure-based inhibitors. CRl acts intrinsically (that is, on the cell on which it is expressed) to inactivate $\mathrm{C} 3$ and $\mathrm{C} 5$ convertases of both the classical and alternative pathways (reviewed in refs. 8,62,73). A naturally occurring soluble form of the molecule (sCR1) has been described in plasma under normal and inflammatorv conditions (74). 


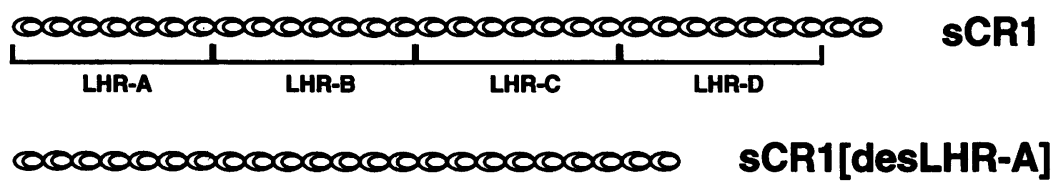

00000000000000000000 sCR1sLe
Fig. 2. Schematic representation of the structure of several complement inhibitors. The protein motif structure of many of the complement inhibitors described in the text are shown here. Most of the inhibitors that block activation of complement through the $\mathrm{C} 3$ convertases are composed of short-census repeat (SCR) protein motifs. Each SCR is approximately 60 to 70 amino acids long and contains four cysteine residues that are disulfide bonded within each SCR (cysteine 1 to cysteine 3 and cysteine 2 to cysteine 4 ). The result is a rod-like, elongated structure, although there is considerable flexibility in the overall structure. For a more detailed discussion of these structures, see references listed in the text. LHR, long homologous repeat; sLe $^{\mathrm{x}}$, sialyl Lewis $\mathrm{X}$.
Several modified versions of CRl, generated by recombinant approaches, have yielded SCR I proteins with different molecular structures. The most widely used version is a nearly full-length CR1 that lacks the transmembrane and cytoplasmic domains, retaining the 30 SCR modules found in the A allotype. This protein was originally and successfully used in a model of myocardial ischemia/reperfusion (75), but has subsequently been applied to a number of other tissues for ischemia/reperfusion models and a variety of acute and chronic inflammatory disease models, as well as xenotransplantation (reviewed in ref. 6). With respect to CNS applications, $\mathrm{sCR} 1$ has been successfully used in $\mathrm{EAE}$, an animal model for multiple sclerosis (76). In this model, sCR 1, given intraperitoneally, was able to significantly block a highly acute, antibody-mediated form of EAE. These data demonstrate that despite systemic delivery and the large size of SCRl $(\sim 150,000 \mathrm{MW})$, it was effective in inhibiting the acute effector phase of the disease. A chronic EAE model more representative of the disease in humans was not examined. The peripheral nervous system (PNS) diseases, myasthenia gravis, and experimental autoimmune neuritis were also inhibited by systemic administration of SCR1 $(77,78)$. The pharmacokinetics of SCRl in the CNS are unknown, but in the absence of normal plasma turnover mechanisms, the $t_{1 / 2}$ of the $\beta$-phase may exceed that of the reported $30 \mathrm{hr}(79)$. Prolonged systemic use of SCR1 for chronic CNS (or PNS) disease is unlikely, given the potential for infection due to suppression of complement activation (80); however, phase I clinical trials with SCR l have not revealed an increased rate of infection for shorter-term applications (6). Nevertheless, sCR1 and related analogs described below may hold promise for chronic CNS diseases such as MS, where attacks are sporadic and unpredictable. Future success with these potential therapeutics relies on a combination of better diagnostic markers to identify disease onset and in situ delivery methods to target the CNS.

A structural variant of $S C R 1$, in which LHR-A has been deleted (sCR1 [desLHR-A]), has also been used in a number of ischemic and xenotransplantation model systems (Fig. 2) $(6,81)$. This truncated molecule is less efficient at inhibiting the activation of the classical pathway, thus its therapeutic value in CNS disease applications, where the classical pathway is often activated, is questionable. An additional variant is a chimeric $(C R 1)_{2}-\mathrm{F}\left(\mathrm{ab}^{\prime}\right)_{2}$ molecule, which is functionally active in inhibiting complement activation (82). However, this molecule poses a problem for chronic applications because of the immunogenicity of the antibody portion of the protein, thus perhaps limiting its use to acute inflammatory conditions.

Perhaps the more exciting derivatives of SCRl are those produced in LEC11 cells, which express fucosyl transferase activity and thereby add the selectin-binding oligosaccharide, sialyl Lewis $\mathrm{X}\left(\mathrm{sLe}^{\mathrm{x}}\right)$ (Fig. 2). The derivatives $\mathrm{SCR} 1 \mathrm{sLe} \mathrm{C}^{\mathrm{X}}$ and SCRl [desLHR-A] sLe ${ }^{\mathrm{x}}$ have the dual capacity to inhibit complement activation and substan- 
tially reduce neutrophil accumulation in lung injury models (83). Furthermore, there was increased binding of these derivatives (compared to their non-sLe ${ }^{\mathrm{x}}$ forms) in injured tissue in a P-selectin-dependent fashion, demonstrating their ability to localize to inflammatory sites. A more recent study demonstrated that $s C R l s L e^{x}$, produced in LEC1 1 cells, incorporated an average of 10 moles of $\mathrm{sLe}^{\mathrm{x}}$ per mole of sCRlsLe ${ }^{\mathrm{x}}$, while SCR1 [desLHR-A]sLe ${ }^{\mathrm{x}}$ incorporated an average of 8 sLe $^{\mathrm{x}}$ moieties (84). In this same study, U937 cells, a human monocytic cell line, were inhibited from binding to aortic endothelial cells activated with tumor necrosis factor $\alpha$ (TNF- $\alpha$ ) and to surface-absorbed P-selectin-IgG. The SCR1sLe ${ }^{\mathrm{x}}$ and sCR1[desLHR-A]sLe ${ }^{\mathrm{x}}$ molecules have not been evaluated in CNS diseases, but they may provide an additional level of protection, over and above SCR 1 alone, by reducing or preventing the accumulation and infiltration of macrophages and lymphocytes into perivascular spaces and the brain parenchyma.

\section{Decay-Accelerating Factor/Membrane Cofactor Protein and Derivatives}

DAF and MCP are structurally similar to CR 1 in that they are composed primarily of SCRs. Each protein has four SCRs that are in tandem but are attached to the cell membrane through different structural domains. DAF is a GPI-anchored protein, whereas MCP has a transmembrane domain (reviewed in refs. 8,62). Both molecules act intrinsically to inhibit the classical and alternative pathways, but they differ in their mechanisms. DAF accelerates the decay of convertases by the removal of $\mathrm{C} 2 \mathrm{a}$ or $\mathrm{Bb}$ from the convertases, whereas MCP serves as a cofactor in the factor I-mediated cleavage of $\mathrm{C} 3 \mathrm{~b}$ and $\mathrm{C} 4 \mathrm{~b}$ to inactive forms (C3bi and $\mathrm{C} 4 \mathrm{c}$ and $\mathrm{C} 4 \mathrm{~d}$, respectively) (reviewed in refs. 8,62). Soluble versions of both proteins have been described but are individually not as effective as SCR1 in complement inhibition because of their single functional activity (85).

An interesting chimeric protein, complement activation blocker-2 (CAB-2), that overcomes the limitations of using soluble DAF or MCP alone was recently described (86). Structurally, CAB-2 is smaller than SCRl (110 kD), which may permit greater diffusibility. CAB-2 displays both decay-accelerating and factor I cofactor activity in vitro and is functional in vivo in multiple animal models. CAB-2 has good pharmacokinetics with a $t_{1 / 2} \beta$ of $8 \mathrm{hr}$, which may be longer in the CNS compartment. Although not yet assessed in CNS inflammatory diseases, CAB-2 may have good therapeutic potential in the CNS, according to in vivo studies using a murine complement regulatory protein that is functionally equivalent to $\mathrm{CAB}-2$. This protein, complement receptor-related protein y (Crry), is composed of five SCRs and is a membranebound protein acting intrinsically to inhibit complement activation of both the classical and alternative pathways (87). Transgenic mice producing a soluble version of Crry (sCrry) systemically are protected from antibody-induced glomerular injury (88). A transgenic mouse that expresses sCrry in the CNS compartment, under the control of an astrocyte-specific promoter, was generated in our laboratory (89). This model system allows analysis of the role of complement in both acute- and chronic-disease settings, overcoming the problem of cross-species immunogenicity of previous studies $(76,78)$. Preliminary data from an active EAE model system with sCrry mice showed significant protection from disease as assessed by clinical scoring and histopathological analysis. The sCrry transgenic mice had little or no macrophage or T cell infiltration and no demyelination, demonstrating that complement plays a significant role in the effector phase of this disease model ( $N$. Davoust et al., unpublished results). These data also provide strong evidence that inhibiting complement activation in the CNS is therapeutically valuable.

\section{C3 and C5 Inhibitors}

Inhibitors that specifically bind to and prevent the activation of $\mathrm{C} 3$ and $\mathrm{C} 5$ are another class of inhibitors that may be useful in CNS applications. Compstatin, a recently described 13-residue cyclic peptide, binds to $\mathrm{C} 3$ and prevents the generation of $\mathrm{C} 3 \mathrm{a}$ and the $\mathrm{MAC}$ as well as the binding of $\mathrm{C} 3$-derived fragments in two models of extracorporeal circulation $(90,91)$. In addition, compstatin was shown to be effective in prolonging the ex vivo survival of perfused pig xenograft (92). Compstatin is an appealing molecule for CNS applications because of its small size relative to the proteins described above $(1.5 \mathrm{kD}$ compared to $28 \mathrm{kD}$ and larger) and its binding specificity. However, compstatin's blood-brain barrier (BBB) permeability and pharmacokinetics remain to be determined. A further difficulty with compstatin is its high species-specificity (90), thus it may not be suitable for evaluation in most small-animal model systems. 
As previously discussed in What to Target in the Complement System, antibodies that bind to $\mathrm{C} 5$ and inhibit its cleavage to $\mathrm{C} 5 \mathrm{a}$ and $\mathrm{C} 5 \mathrm{~b}$ have proven effective in several inflammatory model systems in both animals and humans (61,93-97). There are two well-described monoclonal antibodies that have been used for these studies, N19/8 (98) and a recombinant, single-chain antibody generated from the variable region of N19/8 (93). None of these model systems has focused on CNS inflammatory diseases. Although the pharmacokinetics of these antibodies are favorable, it remains to be seen whether these reagents can be modified sufficiently to avoid immunogenicity problems and be useful in chronic-disease settings, such as Alzheimer's disease or MS. Transgenic approaches to producing human monoclonal antibodies may be useful in this regard $(99,100)$. The recently described crystal structure for C5 may provide additional therapeutic targets as structure-function relationships are further defined (101).

\section{Protease Inhibitors and Receptor Antagonists}

Synthetic compounds and structure-based drug design have been and continue to be the major focus for developing complement inhibitors (reviewed in ref. 6). Inhibitors targeting the classical pathway serine proteases $\mathrm{Clr}$ and $\mathrm{Cl}$ s have been extensively examined using a variety synthetic derivatives, including amidine and guanidinesubstituted compounds, substituted isocoumarin derivatives, and substituted benzoxazinones (1,102-104). Many of these compounds are selective for $\mathrm{Cl} r$ and have demonstrated functional activity in hemolytic assays. Despite these successes, none of the these compounds has displayed the selectivity in inhibiting Clr or Cls, relative to other serine proteases, that makes them attractive enough for further development as complement-inhibitory therapeutics. Threedimensional models have been constructed of the protease domains for $\mathrm{Clr}$ and $\mathrm{Cls}$ and these may prove useful in the design of more effective and specific inhibitors $(105,106)$.

Factor $\mathrm{D}$, the first complement component to have its three-dimensional structure determined (107), has recently been shown to be a novel self-inhibited serine protease (108). A number of $\mathrm{X}$-ray crystallography studies examining factor D mutants have identified structural features in the active site of the enzyme that may account for its high substrate-specificity and slow catalytic rate. These results also support the concept that factor
D functions through an induced-fit mechanism $(109,110)$. Structure-based drug design studies are underway for factor D, although no highly specific inhibitor has yet been developed (111).

The concept of inhibiting the inflammatory effects of complement activation by generating antagonists for the C5aR has been extensively studied. Early studies described peptides with mixed agonist/antagonist properties; antagonist properties included inhibition of $\mathrm{C} 5 \mathrm{a}$ binding to its receptor, reduced chemotactic function, and inability to degranulate cells or induce superoxide release from neutrophils (112-114). Subsequently, synthetic hexapeptides were developed that had greater binding affinity (nanomolar versus micromolar concentrations) and variable antagonist features, depending on the aromaticity of the residues at position five of the peptide. One of these peptides (NMePhe-Lys-Pro-dChaLeu-dArg, where NMe is $N$-methyl and Cha is cyclohexylalanine) was considered a full antagonist because it prevented degranulation of neutrophils, $\mathrm{Ca}^{2+}$-flux, and chemotaxis (115). In other studies, multiple-antigen peptides (MAPs) derived from the carboxy-terminal region of $\mathrm{C} 5 \mathrm{a}$ (MAP 61-74) displayed antagonistic properties in $\mathrm{Ca}^{2+}$ - and $\beta$-hexosaminidase release assays (116). None of these molecules were examined in any in vivo model system to assess their effectiveness or toxicity.

More recently, recombinant $\mathrm{C} 5 \mathrm{a}$ antagonists have been described that differ from the native molecule in only a few key residues. In particular, substituting a cysteine for the glutamine at position 71 generated an antagonist (C5aRAM) with a $K_{i}$ of $8 \mathrm{nM}$ (117). Further modification of C5aRAM by changing the histidine at position 67 to a phenylalanine resulted in an antagonist with a $\mathrm{K}_{\mathrm{i}}$ of $1 \mathrm{nM}$. In addition, the dimeric form of C5aRAM (C5aRAD) was an effective inhibitor in a number of in vitro assays, including increase in $\mathrm{Ca}^{2+}$ rise, CD1 lb up-regulation, superoxide release, lysozyme release, and chemotaxis (117). More importantly, C5aRAM and C5aRAD were effective in blocking dermal edema and C5a-induced neutropenia, demonstrating their utility in vivo. In an additional study, a C5aR antagonist was generated from a phage library (118). This antagonist (A8) differs from the native molecule in the carboxy terminus, substituting R-S-L-L-R for D-M-Q-L-R at positions 69-73, and eliminates the arginine at position 74 . The $\mathrm{A} 8$ antagonist was highly effective in a number of in vitro and in vivo systems, including in ischemia or reperfusion injury. Toxicity and pharmacokinet- 
ics of the antagonists described in either study were not reported. These data suggest that targeting the $\mathrm{C} 5 \mathrm{aR}$ is more feasible than ever and, given the myriad of functional activities the $\mathrm{C} 5 \mathrm{aR}$ plays in inflammation, merits testing in the CNS.

Receptor antagonists for the C3aR have not been examined nearly as much as those for the $\mathrm{C} 5 \mathrm{aR}$, in part because the C $3 \mathrm{aR}$ has only recently been cloned and structural features important in ligand binding are only now underway (69). Cyclic disulfide analogues of $\mathrm{C} 3 \mathrm{a}$ have been shown to be weak antagonists of $\mathrm{C} 3 \mathrm{a}$ binding to its receptor, but no other functional or in vivo studies have been reported $(119,120)$. Given the widespread expression of this receptor in the CNS, antagonists for the C $3 a \mathrm{R}$ may be as valuable as those for the $\mathrm{C} 5 \mathrm{aR}$, especially if there are significant overlaps in their functional roles in CNS diseases.

\section{Problems to Overcome}

Although the human-specific complement inhibitors described here have not been tested in CNS diseases, many have been used in a variety of animal models with excellent success. The ability of sCrry to block the development of EAE in mice provides additional support for the use of complement inhibitors in CNS disease. Despite this promising new avenue, there are still substantial problems that need to be addressed before this group of inhibitors may be clinically useful. Perhaps one of the biggest challenges is the delivery of large molecules to the CNS. All of the inhibitors described here have molecular weights of $>1.5 \mathrm{kD}$ and many are $>50,000$ in molecular weight. Because the $\mathrm{BBB}$ only permits the passage of ionized watersoluble molecules with a molecular weight of 180 or less $(121,122)$, none of the complement inhibitors described above is likely to reach the CNS without a breach in the BBB due to inflammation or through alternative mechanisms. Nevertheless, there are many advances being made in targeting the CNS for therapeutic purposes, including direct convective delivery $(123,124)$, osmotic BBB disruption (122), lipophilic agents $(125,126)$, andenoviruses (127), and stem-cell engraftment $(128,129)$. Many of these approaches would be suitable for the delivery of complement inhibitors to the CNS. Adenoviruses and stem cells may be particularly important for the delivery complement inhibitors to the CNS as diseases such as MS or
Alzheimer's may require continuous delivery over extended periods of time.

\section{Conclusions}

Although there is much to be done to determine the potential efficacy of complement inhibitors in CNS inflammatory diseases, this area of research has an exciting future. The "decade of the brain" has clearly shown that the brain is not an immune-privileged site as previously believed, but, rather, is an immunocompetent organ. Thus much of what is known for the immune system and inflammation outside the CNS may apply to the brain as well, making it possible to uncover the etiology of CNS diseases and therapies at a much faster pace. Furthermore, the recent determination of the three-dimensional structure of some complement proteins makes it likely that the structures of many other proteins will follow. These data may lay the groundwork for even smaller site-specific inhibitors of the complement system as the protein-protein interactions of the molecules involved in complement activation and/or function are deciphered. Perhaps in the near future complement inhibitory reagents will be part of the standard clinical therapy used in CNS diseases. Even if these therapeutics provide only partial protection from disease, they may still be important for quality-of-life issues in terms of reduced neurodegeneration in Alzheimer's disease or neurological sequelea in traumatic brain injury or bacterial meningitis.

\section{Acknowledgments}

The author acknowledges the continuing support and helpful discussions of Drs. Robert Ames, Iain Campbell, Nathalie Davoust, Mark Emmerling, Michael Holers, Serge Nataf, and Philip Stahel. Drs. Lee, Lifeson, and Peart at the RUSH Clinic are acknowledged for their continuing inspiration. This work was supported in part by NIH grants NS29719 and NS38901.

\section{References}

1. Spiegel K, Emmerling MR, Barnum SR. (1997) Acute phase proteins: Strategies for inhibition of complement activation in the treatment of neurodegenerative disorders. In: Wood $\mathrm{P}$, (ed). Inflammatory Mechanisms and Management of Neurodegeneration. Humana Press, Totowa, NJ, pp. 129-176. 
2. Morgan BP, Gasque P, Singhrao S, Piddlesden SJ. (1997) The role of complement in disorders of the nervous system. Immunopharmacology 38: 4350 .

3. Yasojima K, Schwab C, McGeer EG, McGeer PL. (1999) Up-regulated production and activation of the complement system in Alzheimer's disease brain. Am. J. Pathol. 154: 927-936.

4. Nataf S, Stahel PF, Davoust N, Barnum SR. (1999) Complement anaphylatoxin receptor expression on neurons: New tricks for old receptors? Trends Neurosci. 22: 397-402.

5. Liszewski MK, Atkinson JP. (1998) Novel complement therapeutics. Exp. Opin. Invest. Drugs 7: 323-332.

6. Makrides SC. (1998) Therapeutic inhibition of the complement system. Pharmacol. Rev. 50: 5988.

7. Morgan BP. (1995) Complement regulatory molecules: Application to therapy and transplantation. Immunol. Today 16: 257-259.

8. Morgan BP, Harris CL (eds). (1999) Complement Regulatory Proteins. Academic Press, San Diego.

9. Pascual M, French LE. (1995) Complement in human diseases: Looking towards the 21 st century. Immunol. Today 16: 58-61.

10. Buhler L, Friedman T, Iacomini J, Cooper DK. (1999) Xenotransplantation-state of the artupdate 1999. Front. Biosci. 4: D416-D432.

11. McGeer PL, McGeer EG. (1999) Inflammation of the brain in Alzheimer's disease: Implications for therapy. J. Leukoc. Biol. 65: 409-415.

12. Shoulson I. (1998) Experimental therapeutics of neurodegenerative disorders: Unmet needs. Science 282: 1071-1074.

13. Ernst RL, Hay JW. (1994) The U.S. economic and social costs of Alzheimer's disease revisited. Am. J. Public Health 84: 1261-1264.

14. Scolding NJ, Morgan BP, Compston DA. (1998) The expression of complement regulatory proteins by adult human oligodendrocytes. J. Neuroimmunol. 84: 69-75.

15. Gasque P, Singhrao SK, Neal JW. (1998) The anaphylatoxin receptor for complement $\mathrm{C} 3 \mathrm{a}$ is expressed by rat microglia and rat oligodendrocytes. Role in cell chemotaxis and cell activation. J. Neuroimmunol. 90: 21 A.

16. Stahel PF, Morganti-Kossmann MC, Kossmann T. (1998) The role of complement in traumatic brain injury. Brain Res. Rev. 27: 243-256.

17. Broadwell RD, Sofroniew MV. (1993) Serum proteins bypass the blood-brain barrier for extracellular entry to the central nervous system. Exp. Neurol. 120: 245-263.

18. Kossmann T, Stahel PF, Morganti-Kossmann MC, Jones J, Barnum SR. (1997) Elevated levels of the complement components $\mathrm{C} 3$ and factor $\mathrm{B}$ in ventricular cerebrospinal fluid of patients with traumatic brain injury. J. Neuroimmunol. 73: 6369.
19. Stahel PF, Nadal D, Pfister HW, Paradisis PM, Barnum SR. (1997) Increased cerebrospinal fluid levels of complement components $\mathrm{C} 3$ and factor $\mathrm{B}$ discriminate bacterial from viral meningitis. Lancet 349: 1886-1887.

20. Stahel PF, Frei K, Fontana A, Eugster HP, Ault BH, Barnum SR. (1997) Evidence for intrathecal synthesis of alternative pathway complement activation proteins in experimental meningitis. Am. J. Pathol. 151: 897-904.

21. Stahel PF, Frei K, Eugster HP, et al. (1997) TNF$\alpha$-mediated expression of the receptor for anaphylatoxin $\mathrm{C} 5 \mathrm{a}$ (C5aR) on neurons in experimental Listeria meningocephalitis. J. Immunol. 159: $861-869$.

22. Gasque P, Singhrao SK, Neal JW, et al. (1998) The receptor for complement anaphylatoxin C3a is expressed by myeloid cells and non-myeloid cells in inflamed human central nervous system: Analysis in multiple sclerosis and bacterial meningitis. J. Immunol. 160: 3543-3554.

23. Müller-Ladner U, Jones J, Gay S, Wetsel RA, Raine C, Barnum SR. (1996) Enhanced expression of chemotactic receptors in multiple sclerosis lesions. J. Neurol. Sci. 144: 135-144.

24. Gasque P, Singhrao SK, Neal JW, Götze O, Morgan BP. (1997) Expression of the receptor for the complement $\mathrm{C} 5 \mathrm{a}$ (CD88) is up-regulated on reactive astrocytes, microglia, and endothelial cells in the inflamed human central nervous system. Am. J. Pathol. 150: 31-41.

25. Nataf S, Davoust N, Barnum SR. (1998) Kinetics of anaphylatoxin $\mathrm{C} 5 \mathrm{a}$ receptor during experimental allergic encephalomyelitis. J. Neuroimmunol. 91: 147-155.

26. Nataf S, Davoust N, Ames R, Barnum SR. (1999) Human T-cells express the $\mathrm{C} 5 \mathrm{a}$ receptor and are chemotattracted to C5a. J. Immunol. 162: 40184023.

27. Davoust N, Jones J, Stahel PF, Ames R, Barnum SR. (1999) The receptor for the C3a anaphylatoxin is expressed by glial cells and neurons in the normal and inflammed central nervous system. Glia 26: 201-211.

28. Stahel PF, Kossmann T, Hans V, Morganti-Kossmann MC, Barnum SR. (1997) Experimental diffuse axonal injury induces enhanced neuronal C5a receptor expression in rats. Mol. Brain Res. 150: 205-212.

29. Pasinetti GM, Johnson SA, Rozovsky I, et al. (1992) Complement $\mathrm{Clq}$ and C4 mRNAs responses to lesioning in the rat brain. Exp. Neurol. 118: 117-125.

30. Campbell IL, Stalder AK, Akwa Y, Pagenstecher A, Asensio V. (1998) Transgenic models to study the actions of cytokines in the central nervous system. Neuroimmunomodulation 5: 126-135.

31. Barnum SR, Jones J, Müller-Ladner U, Samini A, Campbell IL. (1996) Chronic complement C3 gene expression in the CNS of transgenic mice 
with astrocyte-targeted interleukin 6 expression. Glia 18: 107-117.

32. Paradisis PM, Campbell IL, Barnum SR. (1998) Elevated complement $\mathrm{C} 5$ a receptor expression on glial cells and neurons induced by the central nervous system production of interleukin-3 in transgenic mice. Glia 24: 338-345.

33. Volanakis JE, Frank MM (eds). (1998) The Human Complement System in Health and Disease. Marcel Dekker, New York.

34. Wetsel RA. (1995) Structure, function and cellular expression of complement anaphylatoxin receptors. Curr. Opin. Immunol. 1: 48-53.

35. Ember JA, Jagels MA, Hugli TE. (1998) Anaphylatoxins and biological responses. In: Volanakis JE, Frank MM (eds). The Human Complement System in Health and Disease. Marcel Dekker, New York, pp. 241-284.

36. Czermak BJ, Sarma V, Bless NM, Schmal H, Friedl HP, Ward PA. (1999) In vitro and In vivo dependency of chemokine generation on C5a and TNF-alpha. J. Immunol. 162: 2321-2325.

37. Glabinski AR, Ransohoff RM. (1998) Chemokines and chemokine receptors in CNS pathology. J. Neurovirol. 5: 3-12.

38. Benvensite EN. (1998) Cytokine actions in the central nervous system. Cytokine Growth Factor Rev. 9: 259-275.

39. Martiney JA, Cuff C, Litwak M, Berman J, Brosnan CF. (1998) Cytokine-induced inflammation in the central nervous system revisited. Neurochem. Res. 23: 349-359.

40. McCoy R, Haviland DL, Molmenti EP, Ziambaras T, Wetsel RA, Perlmutter DH. (1995) N-formylpeptide and complement $\mathrm{C} 5 \mathrm{a}$ receptors are expressed in liver cells and mediate hepatic acute phase gene regulation. J. Exp. Med. 182: 207-217.

41. Sayah S, Ischenko AM, Zhakhov A, Bonnard AS, Fontaine M. (1999) Expression of cytokines by human astrocytomas following stimulation by C3a and C5a anaphylatoxins: Specific increase in interleukin-6 mRNA expression. J. Neurochem. 72: 226-236.

42. Czermak BJ, Lentsch AB, Bless NM, Schmal H, Friedl HP, Ward PA. (1999) Synergistic enhancement of chemokine generation and lung injury by $\mathrm{C} 5 \mathrm{a}$ or the membrane attack complex of complement. Am. J. Pathol. 154: 1513-1524.

43. Webster S, Lue LF, Brachova L, et al. (1997) Molecular and cellular characterization of the membrane attack complex, C5b-9, in Alzheimer's disease. Neurobiol. Aging 18: 415-421.

44. Storch MA, Piddlesedn S, Haltia M, Iivanainen M, Morgan B, Lassmann H. (1998) Multiple sclerosis: In situ evidence for antibody- and complement-mediated demyelination. Ann. Neurol. 43: 465-471.

45. Ottonello L, Corcione A, Tortolina G, et al. (1999) rC5a directs the in vitro migration of human memory and naive tonsillar B lymphocytes:
Implications for B cell trafficking in secondary lymphoid tissues. J. Immunol. 162: 6510-6517.

46. Armstrong RC, Harvath L, Dubois-Dalcq ME. (1990) Type 1 astrocytes and oligodendrocytetype 2 astrocyte glial progenitors migrate toward distinct molecules. J. Neurosci. Res. 27: 400-407.

47. Yao J, Harvath L, Gilbert DL, Colton CA. (1990) Chemotaxis by a CNS macrophage, the microglia. J. Neurosci. Res. 27: 36-42.

48. Foreman KE, Vaporciyan AA, Bonish BK, et al. (1994) C5a-induced expression of P-selectin in endothelial cells. J. Clin. Invest. 94: 1147-1155.

49. Foreman KE, Glovsky MM, Warner RL, Horvath SJ, Ward PA. (1996) Comparative effects of C3a and $\mathrm{C} 5 \mathrm{a}$ on adhesion molecule expression on neutrophils and endothelial cells. Inflammation 20: 1-9.

50. Mulligan MS, Schmid E, Till GO, et al. (1997) C5a-dependent up-regulation in vivo of lung vascular P-selectin. J. Immunol. 158: 1857-1861.

51. Kilgore KS, Ward PA, Warren JS. (1998) Neutrophil adhesion to human endothelial cells is induced by the membrane attack complex: The roles of P-selectin and platelet actuvating factor. Inflammation 22: 583-598.

52. Low JL, Ai R, Ogata RT. (1999) Active sites in complement components $\mathrm{C} 5$ and $\mathrm{C} 3$ identified by proximity to indels in the $\mathrm{C} 3 / 4 / 5$ protein family. J. Immunol. 162: 6580-6588.

53. Rogers J, Cooper NR, Webster S, et al. (1992) Complement activation by $\beta$-amyloid in Alzheimer disease. Proc. Natl. Acad. Sci. U.S.A. 89: 10016-10020.

54. Jiang H, Burdock D, Glabe CG, Cotman CW, Tenner AJ. (1994) $\beta$-amyloid activates complement by binding to a specific region of the collagen-like domain of the Clq A chain. J. Immunol. 152: 5050-5059.

55. Velasquez $\mathrm{P}$, Cribbs DH, Poulos TL, Tenner AJ. (1997) Aspartate residue 7 in amyloid beta-protein is critical for classical complement pathway activation: Implications for Alzheimer's disease pathogenesis. Nat. Med. 3: 77-79.

56. Watson MD, Roher AE, Kim KS, Speigel K, Emmerling MR. (1997) Complement interactions with amyloid b1-42: A nidus for inflammation in AD brains. Amyloid: Int. J. Exp. Clin. Invest. 4: 147-156.

57. Bradt BM, Kolb WP, Cooper NR. (1998) Complement-dependent proinflammatory properties of the Alzheimer's disease beta-peptide. J. Exp. Med. 188: 431-438.

58. Meri S, Pangburn MK. (1990) A mechanism of activation of the alternative pathway by the classical pathway: Protection of $\mathrm{C} 3 \mathrm{~b}$ from inactivation by covalent attachment to C4b. Eur. J. Immunol. 20: 2555-2561.

59. Reid KBM, Turner MW. (1994) Mammalian lectins in activation and clearance mechanisms in- 
volving the complement system. Springer Semin. Immunopathol. 15: 307-326.

60. Matsushita M. (1996) The lectin pathway of the complement system. Microbiol. Immunol. 40: 887893.

61. Matis LA, Rollins SA. (1995) Complement-specific antibodies: Designing novel anti-inflammatories. Nat. Med. 8: 839-842.

62. Liszewski MK, Atkinson JP. (1998) Regulatory proteins of complement. In: Volanakis JE, Frank MM (eds). The Human Complement System in Health and Disease. Marcel Dekker, New York, pp. 149-166.

63. Kirk AD, Burkly LC, Batty DS, et al. (1999) Treatment with humanized monoclonal antibody against CD154 prevents acute renal allograft rejection in nonhuman primates. Nat. Med. 5: 686-693.

64. Rollins SA, Matis LA, Springhorn JP, Setter E, Wolff DW. (1995) Monclonal antibodies directed against human C5 and C8 block complementmediated damage of xenogeneic cells and organs. Transplantation 60: 1284-1292.

65. Fodor WL, Rllins SA, Guilmette ER, Setter E, Squinto SP. (1995) A novel bifunctional chimeric complement inhibitor that regulates $\mathrm{C} 3$ convertase and formation of the membrane attack complex. J. Immunol. 155: 4135-4138.

66. Rooney IA, Heuser JE, Atkinson JP. (1996) GPIanchored complement regulatory proteins in seminal plasma. An analysis of their physical condition and the mechanisms of their binding to exogenous cells. J. Clin. Invest. 97: 1675-1686.

67. Stahel PF, Barnum SR. (1997) Bacterial meningitis: Complement gene expression in the central nervous system. Immunopharmacology 38: 65-72.

68. Barker MD, Monk PN. (1997) Structure-function relationships of leucocyte chemoattractant receptors. Biochem. Soc. Trans. 25: 1027-1031.

69. Crass T, Ames RS, Sarau HM, et al. (1999) Chimeric receptors of the human $\mathrm{C} 3 \mathrm{a}$ receptor and C5a receptor (CD88). J. Biol. Chem. 274: 83678370.

70. Klickstein LB, Wong WW, Smith JA, Weis JH, Wilson JG, Fearon DT. (1987) Human C3b/C4b receptor (CRl). Demonstration of long homologous repeating domains that are composed of the short consensus repeats characteristic of $\mathrm{C} 3 / \mathrm{C} 4$ binding proteins. J. Exp. Med. 165: 1095-1112.

71. Krych M, Hourcade D, Atkinson JP. (1991) Sites within the complement $\mathrm{C} 3 \mathrm{~b} / \mathrm{C} 4 \mathrm{~b}$ receptor important for the specificity of ligand binding. Proc. Natl. Acad. Sci. U.S.A. 88: 4353-4357.

72. Lea S, Powell R, Evans D. (1999) Crystallization and preliminary X-ray diffraction analysis of a biologically active fragment of CD55. Acta Crystallogr. D Biol. Crystallogr. 55: 1198-1200.

73. Ahearn JM, Rosengard AM. (1998) Complement receptors. In: Volanakis JE, Frank MM (eds). The
Human Complement System in Health and Disease. Marcel Dekker, New York, pp. 167-202.

74. Pascual M, Duchosal MA, Steiger G, et al. (1993) Circulating soluble CR1 (CD35): Serum levels in diseases and evidence for its release by human leukocytes. J. Immunol. 151: 1702-1711.

75. Weisman HF, Bartow T, Leppo MK, et al. (1990) Soluble human complement receptor typw 1 : In vivo inhibitor of complement suppressing postischemic myocardial inflammation and necrosis. Science 249: 146-151.

76. Piddlesden SJ, Storch MK, Hibbs M, Freeman AM, Lassman H, Morgan BP. (1994) Soluble recombinant complement receptor 1 inhibits inflammation and demyelination in antibody-mediated demyelinating experimental allergic encephalomyelitis. J. Immunol. 152: 5477-5484.

77. Jung S, Toyka KV, Hartung HP. (1995) Soluble complement receptor type 1 inhibits experimental autoimmune neuritis in Lewis rats. Neurosci. Lett. 200: 167-170.

78. Piddlesden SJ, Jiang SS, Levin JL, Vincent A, Morgan BP. (1996) Soluble complement receptor 1 (sCRl) protects against experimental autoimmune myasthenia gravis. J. Neuroimmunol. 71: 173-177.

79. Dellinger RP, Zimmerman JL, Straube RC, et al. (1996) Results of a phase I trial of soluble complement receptor type 1 (TP10) in acute lung injury (ALI). Crit. Care Med. 24 (Suppl. 2): A29.

80. Swift AJ, Collins TS, Bugelski P, Winkelstein JA. (1994) Soluble complement receptor type 1 inhibits complement-mediated host defense. Clin. Diagn. Lab. Immunol. 1: 585-589.

81. Scesney SM, Makrides SC, Gosselin ML, et al. (1996) A soluble deletion mutant of the human complement receptor type 1, which lacks the $\mathrm{C} 4 \mathrm{~b}$ binding site, is a selective inhibitor of the alternative complement pathway. Eur. J. Immunol. 26: 1729-1735.

82. Kalli KR, Hsu PH, Bartow, et al. (1991) Mapping of the $\mathrm{C} 3 \mathrm{~b}$ binding sites of $\mathrm{CRl}$ and construction of a $(\mathrm{CRl})_{2}-\mathrm{F}\left(\mathrm{ab}^{\prime}\right)_{2}$ chimeric complement inhibitor. J. Exp. Med. 174: 1451-1460.

83. Mulligan MS, Warner RL, Rittershaus CW, et al. (1999) Endothelial targeting and enhanced antiinflammatory effects of complement inhibitors possessing sialyl Lewis ${ }^{\mathbf{x}}$ moieties. J. Immunol. 162: 4952-4959.

84. Ritterhaus CW, Thomas LJ, Miller DP, et al. (1999) Recombinant glycoproteins that inhibit complement activation and also bind the selectin adhesion molecules. J. Biol. Chem. 274: 1123711244.

85. Christiansen D, Milland J, Thorley BR, McKenzie IFC, Loveland BE. (1996) A functional analysis of recombinant soluble CD46 in vivo and a comparison with recombinant soluble forms of CD55 and CD35 in vitro. Eur. J. Immunol. 26: 578-585. 86. Higgins PJ, Ko JL, Lobell R, Sardonini C, Alessi 
MK, Yeh CG. (1997) A slouble chimeric inhibitor complement inhibitory protein that possess both decay-accelerating and factor I cofactor activies. J. Immunol. 158: 2872-2881.

87. Kim YU, Kinoshita T, Molina H, et al. (1995) Mouse complement regulatory protein Crry/p65 uses the specific mechanisms of both human decay-accelerating factor and membrane cofactor protein. J. Exp. Med. 181: 151-159.

88. Quigg RJ, He C, Lim A, et al. (1998) Transgenic mice overexpressing the complement inhibitor crry as a soluble protein are protected from antibody-induced glomerular injury. J. Exp. Med. 188: 1321-1331.

89. Davoust N, Nataf S, Holers MV, Berthiaume D, Campbell IL, Barnum SR. (1998) Development of transgenic mice with astrocyte-targeted expression of a soluble inhibitor of complement. J. Neuroimmunol. 90: 47A.

90. Sahu A, Kay BK, Lambris JD. (1996) Inhibition of human complement by a C3-binding peptide isolated from a phage-displayed random peptide library. J. Immunol. 157: 884-891.

91. Nilsson B, Larsson R, Hong J, et al. (1998) Compstatin inhibits complement and cellular activation in whole blood in two models of extracorporeal circulation. Blood 92: 1661-1667.

92. Fiane AE, Mollnes TE, Videm V, et al. (1999) Prolongation of ex vivo-perfused pig xenograft survival by the complement inhibitor compstatin. Transplant. Proc. 31: 934-935.

93. Evans MJ, Rollins SA, Wolff DW, et al. (1995) In vitro and in vivo inhibition of complement activity by a single chain Fv fragment recognizing human C5. Mol. Immunol. 32: 1183-1195.

94. Wang Y, Rollins SA, Madri JA, Matis LA. (1995) Anti-C5 monoclonal antibody therapy prevents collagen-induced arthritis and ameliorates established disease. Proc. Natl. Acad. Sci. U.S.A. 92: 8955-8959.

95. Wang Y, Hu Q, Madri JA, Rollins SA, Chodera A, Matis LA. (1996) Amelioration of lupus-like autoimmune disease in NXB/W Fl mice after treatment with a blocking monoclonal antibody specific for complement component C5. Proc. Natl. Acad. Sci. U.S.A. 93: 8563-8568.

96. Thomas TC, Rollins SA, Rother RP, et al. (1996) Inhibition of complement activity by humanized anti-C5 antibody and single-chain Fv. Mol. Immunol. 33: 1389-1401.

97. Vakeva AP, Agah A, Rollins SA, Matis LA, Li L, Stahl GL. (1998) Myocardial infarction and apoptosis after myocardial ischemia and reperfusion. Role of the terminal complement components and inhibition by anti-C5 therapy. Circulation 97: 2259-2267.

98. Würzner R, Schultze M, Happe L, et al. (1991) Inhibition of terminal complement complex formation and cell lysis by monoclonal antibodies. Complement Inflamm. 8: 328-340.
99. Morrison SL, Shin SU. (1995) Genetically engineered antibodies and their application to brain delivery. Adv. Drug Delivery Res. 15: 147-175.

100. Brüggemann M, Taussig MJ. (1997) Production of human antibody repertoires in transgenic mice. Curr. Opin. Biotechnol. 8: 455-458.

101. Discipio RG, Jenner L, Thirup S, Sottrup-Jensen L, Nyborg J, Stura E. (1998) Crystallization of human complement component C5. Acta Crystallogr. D Biol. Crystallogr. 54: 643-646.

102. Hays SJ. (1998) Therapeutic approaches to the treatment of neuroinflammatory disease. Curr. Pharm. Design 4: 335-348.

103. Hays SJ, Caprathe BW, Gilmore JL, et al. (1998) 2-amino-4H-3,1-benzoxazin-4-ones as inhibitors of $\mathrm{Clr}$ serine protease. J. Med. Chem. 41: 1060-1067.

104. Plummer JS, Cai C, Hays SJ, et al. (1999) Benzenesulfonamide derivatives of 2-substituted 4H-3,1-benzoxazin-4-ones and benzthiazin-4ones as inhibitors of complement Clr protease. Bioorg. Med. Chem. Lett. 9: 815-820.

105. Rossi V, Gaboriaud C, Lacroix M, et al. (1995) Structure of the catalytic region of human complement protease C1s: Study by chemical crosslinking and three-dimensional homology modeling. Biochemistry 34: 7311-7321.

106. Lacroix M, Rossi V, Gaboriaud C, et al. (1997) Structure and assembly of the catalytic region of human complement protease Clr: A three-dimensional model based on chemical cross-linking and homology modeling. Biochemistry 36: 6270-6282.

107. Narayana SVL, Carson M, El-Kabbani O, et al. (1994) Structure of human factor D, a complement system protein at $2.0 \AA$ resolution. J. Mol. Biol. 235: 695-708.

108. Jing H, Macon $\mathrm{KJ}$, Moore D, DeLucas LJ, Volanakis JE, Narayana SV. (1999) Structural basis of profactor D activation: From a highly flexible zymogen to a novel self-inhibiting serine protease, complement factor D. EMBO J. 18: 804814.

109. Volanakis JE, Arlaud GJ. (1998) Complement enzymes. In: Volanakis JE, Frank MM (eds). The Human Complement System in Health and Disease. Marcel Dekker, New York, pp. 49-81.

110. Taylor FR, Bixler SA, Budman JI, et al. (1999) Induced fit activation mechanism of the exceptionally specific serine protease, complement factor D. Biochemistry 38: 2849-2859.

111. Cole LB, Kilpatrick JM, Chu N, Babu YS. (1998) Structure of 3,4-dichloroisocoumarin-inhibited factor D. Acta Crystallogr. D Biol. Crystallogr. 54: 711-717.

112. Mollison KW, Krause RA, Fey TA, et al. (1992) Hexapeptide analogues of $\mathrm{C} 5 \mathrm{a}$ anaphylatoxin reveal heterogeneous neutrophil agonism/antagonism. FASEB J. 6: A2058.

113. Lanza TJ, Durette PL, Rollins T, et al. (1992) 
Substituted 4,6-diaminoquinolines as inhibitors of C5a receptor binding. J. Med. Chem. 35: 252258.

114. Drapeau G, Brochu S, Godin D, Levesque L, Rioux F, Marceau F. (1993) Synthetic C5a receptor agonists. Pharmacology, metabolism and in vivo cardiovascular and hematologic effects. Biochem. Pharmacol. 45: 1289-1299.

115. Konteatis ZD, Siciliano SJ, Van Riper G, et al. (1994) Development of C5a receptor antagonists. Differential loss of functional responses. J. Immunol. 153: 4200-4205.

116. Kaneko Y, Okada N, Baranyi L, Azuma T, Okada H. (1995) Antagonistic peptides against human anaphylatoxin C5a. Immunology 86: 149-154.

117. Pellas TC, Boyar W, van Oostrum J, et al. (1998) Novel C5a receptor antagonists regulate neutrophil functions in vitro and in vivo. J. Immunol. 160: $5616-5621$.

118. Heller T, Hennecke M, Baumann U, et al. (1999) Selection of a $\mathrm{C} 5 \mathrm{a}$ receptor antagonist from phage libraries attenuating the inflammatory response in immune complex disease and ischemia/reperfusion injury. J. Immunol. 163: 985994.

119. Kretzchmar T, Pohl M, Casaretto M, et al. (1992) Synthetic antagonists of the anaphylatoxin C3a. Eur. J. Biochem. 210: 185-191.

120. Pohl M, Ambrosius D, Grötzinger J, et al. (1993) Cyclic disulfide analogues of the complement component C3a: Synthesis and conformational investigations. Int. J. Pept. Res. 41: 362-375.

121. Abbott NJ, Romero IA. (1996) Transporting therapeutics across the blood-brain barrier. Mol. Med. Today 2: 106-113.
122. Kroll RA, Neuwelt EA. (1998) Outwitting the blood-brain barrier for therpeutic purposes: Osmotic opening and other means. Neurosurgery 42 : 1083-1100.

123. Laske DW, Morroson PF, Lieberman DM. (1997) Chronic interstitia infusion of proteins to the primate brain: Determination of drug distribution and clearance with single-photon emission computerized tomography imaging. J. Neurosurg. 87: $586-594$.

124. Lonser RR, Gogate N, Morrison PF, Wood JD, Oldfield EH. (1998) Direct conventive delivery of macromolecules to the spinal cord. J. Neurosurg. 89: $616-622$.

125. Huwyler J, Wu D, Pardridge WM. (1996) Brain drug delivery of small molecules using immunoliposomes. Proc. Natl. Acad. Sci. U.S.A. 93: 1416414169.

126. Prokai-Tatrai K, Prokai L, Bodor N. (1996) Braintargeted delivery of a leucine-enkephalin analogue by retrometabolic design. J. Med. Chem. 39: 4775-4782.

127. Barkats M, Bilang-Bleuel A, Buc-Caron $\mathrm{MH}$, et al. (1998) Adenovirus in the brain: Recent advances of gene therapy for neurodegenerative diseases. Prog. Neurobiol. 55: 333-34l.

128. Flax JD, Aurora S, Yang C. (1998) Engraftable human neural stem cells respond to developmental cues, replace neurons and express foreign genes. Nat. Biotechnol. 16: 1033-1139.

129. Yandava BD, Billinghurst LL, Snyder EY. (1999) "Global" cell replacement is feasible via neural stem cell transplantation: Evidence from the dysmyelinated shiverer mouse brain. Proc. Natl. Acad. Sci. U.S.A. 96: 7029-7034. 